\title{
A Case of Solitary Fibrous Tumor of Subungual Region
}

\author{
Min Kyun An, Eun Hye Hong, Eun Byul Cho, Eun Joo Park, Kwang Ho Kim, Kwang Joong Kim \\ Department of Dermatology, Hallym University Sacred Heart Hospital, Anyang, Korea
}

Solitary fibrous tumor (SFT) is a relatively uncommon mesenchymal neoplasm that usually arises in the pleura, but also has been reported in numerous extrapleural locations, including cutaneous site. The skin lesion presents as a circumscribed nodule or tumor, mainly on the head and neck. A 41-year-old male presented with 6 months history of nail lesion without symptom on the left third finger. The lesion is slightly yellowish discoloration with subungual erythematous nodule and distal onycholysis. Biopsy specimen from the nail lesion showed the spindle cells form patternless pattern with hypercellular and hypocellular area. And small blood vessels and dilated vascular spaces were present. The result of special stain for specimen showed that positive for CD34, Bcl-2, and CD99 but negative for S-100, FactorXIIIa, and smooth muscle action. Recognition of this uncommon location of SFT is important because of possible confusion with other subungual tumors, including glomus tumor, fibroma and other fibrohistiocytic tumors like dermatofibrosarcoma protuberans, superficial acral fibromyxoma and cellular digital fibroma. Here in, we report a case of SFT of subungual region. We think this case is interesting because of uncommon location and may be helpful to more understand the character of this disease. (Ann Dermatol 32(2) $146 \sim$ 150, 2020)

Received July 23, 2018, Revised December 12, 2018, Accepted for publication December 26, 2018

Corresponding author: Kwang Ho Kim, Department of Dermatology, Hallym University Sacred Heart Hospital, 22 Gwanpyeong-ro 170beon-gil, Dongangu, Anyang 14068, Korea. Tel: 82-31-380-3765, Fax: 82-31-386-3761, E-mail: dermakkh@naver.com

ORCID: https://orcid.org/0000-0001-5315-6031

This is an Open Access article distributed under the terms of the Creative Commons Attribution Non-Commercial License (http://creativecommons. org/licenses/by-nc/4.0) which permits unrestricted non-commercial use, distribution, and reproduction in any medium, provided the original work is properly cited.

Copyright (c) The Korean Dermatological Association and The Korean Society for Investigative Dermatology

\section{-Keywords-}

Neoplasm, Solitary fibrous tumor

\section{INTRODUCTION}

A solitary fibrous tumor (SFT) is a relatively uncommon mesenchymal neoplasm that usually arises in the pleura. While SFTs have been reported to affect various locations, cutaneous SFT has rarely been reported ${ }^{1-3}$. SFTs that clinically involve the skin present as a circumscribed nodule, and most commonly occur in the head and neck. We experienced a case of an STF in the subungual region, which was diagnosed using histopathologic examination. Here, we describe this rare case and provide a literature review.

\section{CASE REPORT}

A 41-year-old male patient visited our hospital with the main complaint of an asymptomatic skin lesion beneath the third left nail of the hand. Six months prior, the patient presented with discoloration on the third left nail, a unilateral lesion beneath the nail, and a growing skin lesion without symptoms. There was no relevant history or family history, and there were no abnormalities in the laboratory findings. The patient's lesion was observed in the third left finger with yellowish discoloration and hypertrophy of the nail accompanied by distal onycholysis and an erythematous nodule on the proximal nail fold (Fig. 1). A punch biopsy was performed under the nail. The biopsy results indicated the presence of several small and dilated blood vessels between irregularly arranged proliferated spindle cells, a hypercellular area with several spindle cells, and a hypocellular area with several collagen fibers. Immunohistochemical staining was performed, which showed that the tumor cells were positive for CD34, Bcl-2, and CD99 and negative for S-100, FactorXIIIa, and smooth muscle action (SMA) (Fig. 2). Based on the clinical features and 

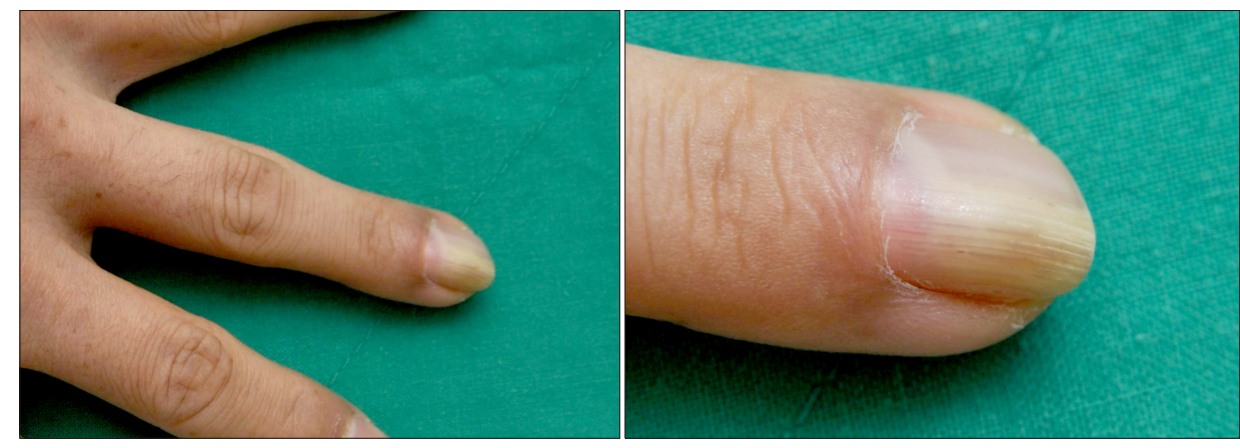

Fig. 1. Slightly yellowish discoloration with hypertrophic nail and distal onycholysis and erythematous subungual nodule on the proximal nail fold of left third finger.
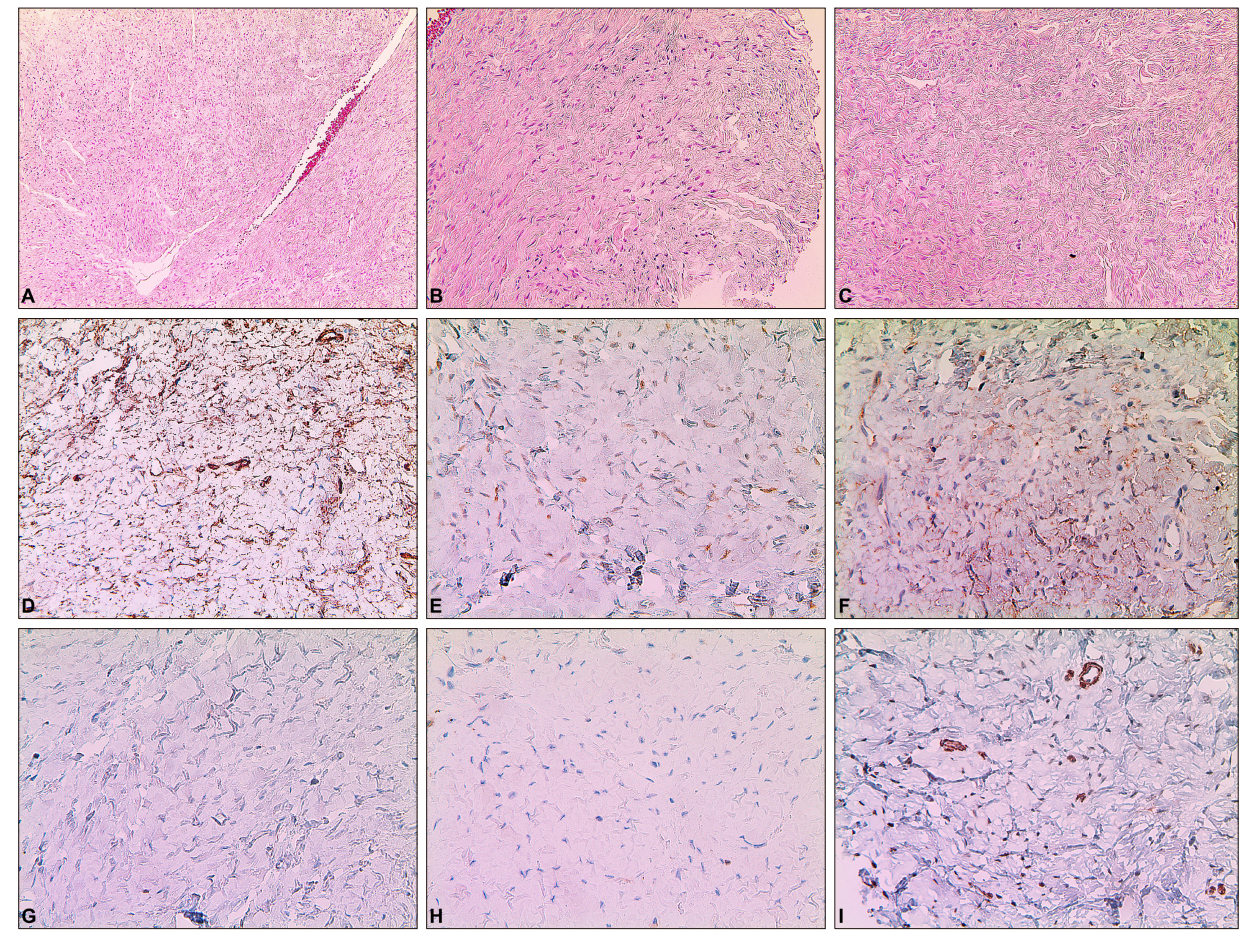

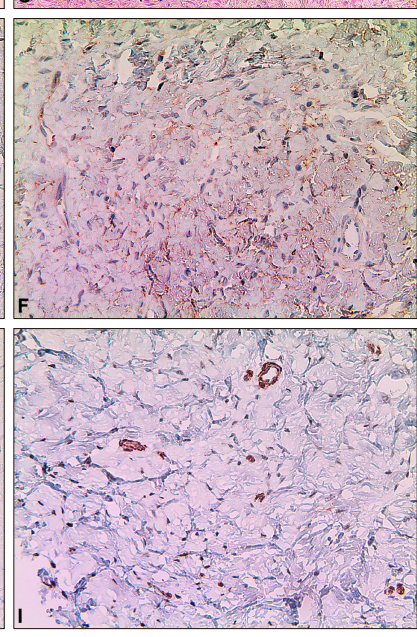

Fig. 2. (A) The biopsy specimen shows proliferation of spindle cells and several small blood vessels and dilated vascular spaces are present $(\mathrm{H} \& \mathrm{E}, \times 100)$. (B) The spindle cells form patternless pattern with hypercellular areas $(H \& E, \times 200)$. (C) The spindle cells form patternless pattern with hypocellular areas (H\&E, $\times 200)$. (D) The tumor cells are diffusely positive for CD34 $(\times 400)$. (E) The tumor cells are positive for Bcl-2 $(\times 400)$. (F) The tumor cells are diffusely positive for CD99 $(\times 400)$. (G) The tumor cells are negative for S-100 $(\times 400)$. (H) The tumor cells are negative for FactorXIIIa $(\times 400)$. (I) The tumor cells are negative for SMA $(\times 400)$. histologic findings, the patient was diagnosed with a subungual SFT. The patient was transferred to the department of plastic surgery for surgical treatment. We received the patient's consent form about publishing all photographic materials.

\section{DISCUSSION}

A SFT is an uncommon neoplasm with a mesenchymal origin that usually arises in the pleura, but is known to occur in other locations, such as the liver, kidney, soft tissue, thyroid, central nervous system, and adrenal glands. Cases of SFT involving the skin are uncommon, but a few have been reported ${ }^{2,3}$.

Clinically cutaneous SFTs was first reported by Okamura et al. $^{3}$. The common cutaneous involvement sites include the head and neck, and cases of SFT development in the trunk and limbs have also been reported ${ }^{4}$. No SFT of the subungual region has been reported anywhere before, and only 10 cases of SFT in atypical skin areas (except head and

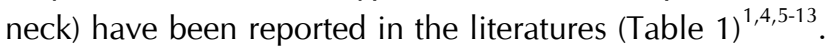
The analysis of those cases showed that there was no difference in the incidence of SFT development between men and women. Furthermore, SFTs can develop in individuals in their 20's to 60 's and vary in size from 1 to $8 \mathrm{~cm}$. Meanwhile, most patients with an SFT experience either no symptoms or localized tenderness. The potential sites of lesion development include the back, torso, arms, and legs.

Histologically, SFTs present as proliferating spindle cells that are similar to fibroblasts and are characterized by a "patternless pattern," as they may exhibit various forms without a specific arrangement. These various forms include a herringbone form, storiform, wavy form, and he- 
Table 1. Previous reported cutaneous solitary fibrous tumors (except head and neck) in literatures

\begin{tabular}{|c|c|c|c|c|c|}
\hline Patient & Age/Sex & Location & Size $(\mathrm{cm})$ & Clinical feature & Staining \\
\hline $1^{7}$ & $36 / F$ & Buttock & $5.0 \times 5.0$ & Not reported & $\begin{array}{l}\text { CD34 }(+) \text {, Vimentin }(+) \text {, Keratin }(-) \text {, Actin }(-), \operatorname{Desmin}(-) \text {, } \\
\text { S-100 }(-) \text {, Collagen type IV }(-) \text {, Factor VIII }(-)\end{array}$ \\
\hline $2^{7}$ & $34 / F$ & Back & $3.5 \times 3.2$ & Not reported & $\begin{array}{l}\text { CD34 }(+) \text {, Vimentin }(+) \text {, Keratin }(-) \text {, Actin }(-) \text {, Desmin }(-) \text {, } \\
\text { S-100 }(-) \text {, Collagen type IV }(-) \text {, Factor VIII }(-)\end{array}$ \\
\hline $3^{7}$ & $34 / F$ & Perineum & $1.6 \times 1.5$ & Not reported & $\begin{array}{l}\text { CD34 }(+) \text {, Vimentin }(+) \text {, Keratin }(-) \text {, Actin }(-) \text {, Desmin }(-) \text {, } \\
\text { S-100 }(-) \text {, Collagen type IV }(-) \text {, Factor VIII }(-)\end{array}$ \\
\hline $4^{7}$ & $43 / \mathrm{M}$ & $\begin{array}{r}\text { Upper } \\
\text { back }\end{array}$ & $6.0 \times 2.3$ & Not reported & $\begin{array}{l}\text { CD34 }(+) \text {, Vimentin }(+) \text {, Keratin }(-) \text {, Actin }(-) \text {, Desmin }(-) \text {, } \\
\text { S-100 }(-) \text {, Collagen type IV }(-) \text {, Factor VIII }(-)\end{array}$ \\
\hline $5^{8}$ & $68 / F$ & Back & $1.0 \times 1.0$ & Not reported & CD34 $(+)$, Calretinin $(-)$, HBME-1 $(-)$ \\
\hline $6^{5}$ & $42 / \mathrm{F}$ & Thigh & $1.0 \times 1.0$ & $\begin{array}{l}\text { Asymptomatic } \\
\text { nodule }\end{array}$ & $\begin{array}{l}\text { CD34 }(+) \text {, Alcian blue }(+) \text {, Colloidal iron }(+), \operatorname{SMA}(-), \text { CD68 }(-) \text {, } \\
\text { S-100 (-) }\end{array}$ \\
\hline $7^{9}$ & $56 / F$ & Back & $4.0 \times 2.0$ & $\begin{array}{l}\text { Asymptomatic } \\
\text { nodule }\end{array}$ & $\begin{array}{l}\text { CD34 }(+) \text {, Vimentin }(+), \operatorname{Bcl}-2(+) \text {, Desmin }(-), \operatorname{SMA}(-), \text { S-100 }(-) \text {, } \\
\text { EMA }(-) \text {, Cytokeratin }(-)\end{array}$ \\
\hline $8^{1}$ & $26 / \mathrm{F}$ & Abdomen & $1.5 \times 1.2$ & $\begin{array}{l}\text { Asymptomatic } \\
\text { nodule }\end{array}$ & $\begin{array}{l}\text { CD34 (+), Vimentin }(+), \operatorname{Bcl}-2(+), \operatorname{CAM} 5.2(-), \operatorname{AE} 1 / \operatorname{AE} 3(-), \\
\operatorname{EAB}-903(-), \operatorname{EMA}(-), \operatorname{SMA}(-), \operatorname{S}-100(-), \text { Melan-A }(-), \\
\operatorname{CD} 68(-), \text { Factor XIII }(-), \operatorname{CD} 31(-)\end{array}$ \\
\hline $9^{10}$ & $49 / \mathrm{F}$ & Shoulder & $8.0 \times 7.0$ & $\begin{array}{l}\text { Asymptomatic } \\
\text { mass }\end{array}$ & $\begin{array}{l}\text { CD34 }(+), \text { Vimentin }(+), \operatorname{BCl}-2(+), \operatorname{CD} 99(+), \text { Cytokeratin }(-), \\
\text { EMA }(-), \text { S-100 }(-), \operatorname{CD} 31(-), \operatorname{Desmin}(-), \operatorname{SMA}(-), \operatorname{p}-53(-), \\
\text { melanosome }(-), \operatorname{CD} 68(-), \operatorname{KIT}(-), \text { Factor VIII }(-)\end{array}$ \\
\hline $10^{6}$ & $64 / \mathrm{M}$ & Back & $3.0 \times 3.0$ & Tender nodule & $\operatorname{CD} 34(+), \operatorname{Bcl}-2(+), \operatorname{CD} 99(+)$, S-100 $(-), \operatorname{SMA}(-)$, Cytokeratin $(-)$ \\
\hline $11^{11}$ & $32 / \mathrm{F}$ & Pubic area & $3.0 \times 3.0$ & Not reported & $\begin{array}{l}\operatorname{CD} 34(+), \operatorname{Bcl}-2(+), \operatorname{CD} 99(+), \operatorname{ER}(+), \operatorname{PgR}(+), \operatorname{Desmin}(-) \\
\text { S-100 }(-), \operatorname{SMA}(-), \operatorname{AE} 1 / \operatorname{AE} 3(-), \operatorname{CD} 31(-)\end{array}$ \\
\hline $12^{12}$ & $46 / F$ & Palm & $1.0 \times 1.0$ & Tender nodule & $\mathrm{CD} 34(+), \mathrm{Bcl}-2(+), \mathrm{S}-100(-), \operatorname{SMA}(-)$ \\
\hline $13^{13}$ & $69 / F$ & Ankle & $0.7 \times 0.8$ & $\begin{array}{l}\text { Asymptomatic } \\
\text { mass }\end{array}$ & CD34 $(+)$, Vimentin $(+)$ \\
\hline
\end{tabular}

F: female, M: male, EMA: epithelial membrane antigen, SMA: smooth muscle action.

mangiopericytoma-like angioplasia form. A SFT may appear histologically similar to dermatofibroma, spindle cell lipoma, leiomyoma, dermatofibrosarcoma protuberans, superficial acral fibromyxoma, cellular digital fibroma, dermatomyofibroma, schwannoma, and hemangiopericytoma, which may include proliferating cells ${ }^{3}$. Therefore, immunohistochemical staining is helpful in diagnosing an SFT. In the literature, the immunohistochemical findings indicate a variation in the positive detection of CD34, CD99, vimentin, and $\mathrm{BCl}-2$ in SFTs and an absence of muscle, neural and epithelial markers ${ }^{1}$.

Genearlly, the CD34 is widely used as marker for differentiating spindle cell pattern tumor. Human CD34 molecule has been originated form myeloid leukemia cell line and used as a marker for hematopoietic progenitor cells. It is also expressed in nonhematopoietic cell types including muscle satellite cells, corneal keratocytes, interstitial cells, epithelial progenitors, and vascular endothelial progenitors. In literature reviews to date, there is no studies reported that CD34 expression imply specific origin. Also there are no reports that SFT is thought to have specific origin. In 2014, Sidney et al. ${ }^{14}$ reported that the CD34 expression associates with progenitor and stem cell activity and corre- lates with cell plasticity. Therefore, considering the facts SFTs show diffuse CD34 expression and arise from various body sites, we believe that the SFTs have progenitor activity in mesenchymal stem cells rather than have specific differentiated origin.

In the present case, we could distinguish the patient's SFT from a muscle origin tumor because the immunohistochemical analysis showed a positive staining for CD34 and a negative staining for SMA. Neurofibromatosis and fibrous histiocytoma could be excluded from positive staining results for S-100. In addition, dermatofibrosarcoma protuberans, in which spindle cells are observed, could be excluded because it is characterized by storiform or a fascicular pattern, and is negative for $\mathrm{Bcl}-2$ and CD99. Superficial acral fibromyxoma shows a spindle cell with a storiform or fascicular pattern and negative findings on $\mathrm{Bcl}-2$ immunohistochemical stain. Also this case did not show myxoid change. And cellular digital fibroma is less than $0.5 \mathrm{~cm}$ in size and has clinical features similar to viral warts. Histologically, proliferation of uniform slender fibroblasts is seen in the fascicles of the fascicles. Based on the aforementioned clinical features and immunohistochemical staining results, this patient was diagnosed with 
an SFT of the subungual region (Table 2) ${ }^{15,16}$. Recently, Doyle et al. ${ }^{17}$ have reported that presence of immunohistochemical stain for signal transductor and activator of transcription 6 (STAT6) and NGFI-A binding protein 2 (NAB2, EGR1 binding protein 2)-STAT6 fusion gene is a highly sensitive and specific markers for SFT. It is limitation that this case not identified the STAT6 immunohistochemical stain or NAB2-STAT6 fusion gene.

Patients with a SFT are usually treated with complete surgical excision. However, no published consent about procedures in the treatment of SFT exists ${ }^{18}$. The rate of local recurrence or distant metastasis or both is $10 \% \sim 13 \%{ }^{18}$. Nielsen et al. ${ }^{19}$ reported that SFT in the extremities are more likely to be malignant. Thus, a wider resection of the tumor and a long term follow-up was proposed. Malignant tumors generally display histological features including hypercellularity, moderate to severe nuclear atypia, stro- mal or vascular invasion, necrosis and high mitotic activity (over 4 per 10 high-power fields) ${ }^{19}$.

To our knowledge, there have been no cases reported occurred in the subungual area. Considering this case report, SFT should be considered in differential diagnosis of soft tissue tumor in subungual area. However, differential diagnosis of acral lesion tumor is broad. And it is difficult to distinguish tumors with similar clinical features and histologically showing spindle cells. Therefore, histologic findings, including immunochemical study, are indispensable to differentiate tumors of other acral lesions including SFT. We report this case as a rare educational case.

\section{CONFLICTS OF INTEREST}

The authors have nothing to disclose.

Table 2. Charateristics of soft tissue tumors associated with acral lesion or spindle cell pattern ${ }^{15,16}$

\begin{tabular}{|c|c|c|c|}
\hline Disease entity & Clinical feature & Histopathological feature & Immunohistochemistry \\
\hline $\begin{array}{l}\text { Acquired digital } \\
\text { fibrokeratoma }\end{array}$ & $\begin{array}{l}\text { Solitary flesh colored } \\
\text { hyperkeratotic papule with } \\
\text { collarette of scale }\end{array}$ & $\begin{array}{l}\text { Vertically oriented collagen and } \\
\text { fibroblasts surrounded by acanthotic, } \\
\text { hyperkeratotic epidermis }\end{array}$ & CD34 $(-)$, Factor XIIIa $(+)$ \\
\hline $\begin{array}{l}\text { Cellular digital } \\
\text { fibroma }\end{array}$ & $\begin{array}{l}\text { Small }(<0.5 \mathrm{~cm}) \text { in diameter, } \\
\text { Predilection for fingers and toes }\end{array}$ & $\begin{array}{l}\text { Poliferation of uniform slender } \\
\text { fibroblasts forming short intersecting } \\
\text { fascicles in parallel }\end{array}$ & $\begin{array}{l}\text { CD34 (+), S100 (-), } \\
\text { Vimentin }(+), \operatorname{CD} 99(-), \\
\text { SMA (-) }\end{array}$ \\
\hline Dermatofibroma & Rarely occurs on the digits & Storiform pattern of spindle cells & $\begin{array}{l}\text { CD34 }(-) \text {, Factor XIIIa }(+), \\
\text { CD99 }(+)\end{array}$ \\
\hline $\begin{array}{l}\text { Dermatofibrosarcoma } \\
\text { protuberans }\end{array}$ & Rarely occurs on the digits & $\begin{array}{l}\text { Diffuse infiltration of spindle cells, } \\
\text { storiform or fascicular pattern, Less } \\
\text { myxoid area extending subcutis }\end{array}$ & $\begin{array}{l}\text { CD34 (+), SMA }(+) \text {, Factor } \\
\text { XIIla }(-) \text {, Vimentin }(+), \text { EMA } \\
(-), \text { S100 }(-) \text {, Desmin }(-)\end{array}$ \\
\hline Glomus tumor & $\begin{array}{l}\text { Paroxismal pain can be } \\
\text { exacerbated by pressure or } \\
\text { temperature changes }\end{array}$ & $\begin{array}{l}\text { Glomus cells are arranged around } \\
\text { vessels, stroma is myxoid appearance }\end{array}$ & $\begin{array}{l}\text { CD34 }(+/-), \text { SMA }(+), \\
\text { Desmin }(-) \text {, Factor VIIla }(-), \\
\text { S100 }(-)\end{array}$ \\
\hline $\begin{array}{l}\text { Low-grade } \\
\text { myxofibrosarcoma }\end{array}$ & $\begin{array}{l}\text { Predilection for proximal } \\
\text { extremities and trunk }\end{array}$ & Significant cytologic atypia and mitoses & $\begin{array}{l}\text { CD34 }(+/-) \text {, Vimentin }(+) \\
\text { Desmin }(-), \text { S100 }(-)\end{array}$ \\
\hline Myxofibrosarcoma & $\begin{array}{l}\text { Predilection for head, neck and } \\
\text { trunk }\end{array}$ & $\begin{array}{l}\text { Storiform of fascicular pattern spindle } \\
\text { cells, Sclerotic collagen at the } \\
\text { periphery, Confined to the dermis }\end{array}$ & $\begin{array}{c}\text { CD34 (-), Vimentin }(+) \text {, CD99 } \\
(+), \text { S100 (-), Cytokeratin } \\
(-) \text {, EMA (-), Factor XIIIa } \\
(+), \text { SMA (+), MSA (+) }\end{array}$ \\
\hline $\begin{array}{l}\text { Myxoid } \\
\text { neurofibroma }\end{array}$ & Rarely $>1 \mathrm{~cm}$ in diameter & $\begin{array}{l}\text { Elongated cells with wavy nuclei, no } \\
\text { significant vascular proliferation }\end{array}$ & $\begin{array}{c}\text { CD34 }(-), \operatorname{CD} 99(-), \text { S100 } \\
(+), \operatorname{EMA}(+), \text { Alcian blue }(+)\end{array}$ \\
\hline Perineuroma & Usually occurs in subcutis & $\begin{array}{l}\text { Spindle cells in interwoven fascicles } \\
\text { demonstrate a whorled or onion-skin } \\
\text { growth pattern }\end{array}$ & $\begin{array}{l}\text { CD34 }(-) \text {, EMA }(-) \text {, Collagen } \\
\text { IV }(-)\end{array}$ \\
\hline Periungual fibroma & $\begin{array}{l}\text { Pink to red, firm conical papules } \\
\text { that emerge from underneath } \\
\text { the proximal nail fold, a } \\
\text { cutaneous manifestation of } \\
\text { tuberous sclerosis complex }\end{array}$ & $\begin{array}{l}\text { Stellate fibroblasts admixed with } \\
\text { vertically oriented dense collagen and } \\
\text { blood vessels }\end{array}$ & NA \\
\hline $\begin{array}{l}\text { Superficial acral } \\
\text { fibromyxoma }\end{array}$ & Predilection for hands and feet & $\begin{array}{l}\text { Proliferation of spindle or stellate cells } \\
\text { with storiform or fascicular pattern, } \\
\text { myxocollagenous stroma }\end{array}$ & $\begin{array}{l}\text { CD34 }(+), \text { S100 }(-), \text { Bcl-2 } \\
(-), \text { CD99 }(+), \text { Vimentin }(+), \\
\text { Alcian blue }(+)\end{array}$ \\
\hline
\end{tabular}

SMA: smooth muscle action, EMA: epithelial membrane antigen, NA: not available. 


\section{ORCID}

Min Kyun An, https://orcid.org/0000-0003-2075-8508

Eun Hye Hong, https://orcid.org/0000-0002-3566-1007

Eun Byul Cho, https://orcid.org/0000-0001-5603-5112

Eun Joo Park, https://orcid.org/0000-0002-9924-515X

Kwang Ho Kim, https://orcid.org/0000-0001-5315-6031

Kwang Joong Kim, https://orcid.org/0000-0003-4158-6100

\section{REFERENCES}

1. Soldano AC, Meehan SA. Cutaneous solitary fibrous tumor: a report of 2 cases and review of the literature. Am J Dermatopathol 2008;30:54-58.

2. Erdag G, Qureshi HS, Patterson JW, Wick MR. Solitary fibrous tumors of the skin: a clinicopathologic study of 10 cases and review of the literature. J Cutan Pathol 2007;34:844850.

3. Okamura JM, Barr RJ, Battifora H. Solitary fibrous tumor of the skin. Am J Dermatopathol 1997;19:515-518.

4. Oh YJ, Lew BL, Sim WY. Primary cutaneous solitary fibrous tumor. Korean J Dermatol 2011;49:1093-1097.

5. Chang SE, Bae GY, Choi JH, Sung KJ, Moon KC, Koh JK, et al. Cutaneous solitary fibrous tumour with myxoid stroma. Br J Dermatol 2002;147:1267-1269.

6. Lee HJ, Lee SH, Roh MR. Cutaneous myxoid solitary fibrous tumour. Clin Exp Dermatol 2012;37:197-199.

7. Suster S, Nascimento AG, Miettinen M, Sickel JZ, Moran CA. Solitary fibrous tumors of soft tissue. A clinicopathologic and immunohistochemical study of 12 cases. Am J Surg Pathol 1995; 19:1257-1266.

8. Morgan MB, Smoller BR. Solitary fibrous tumors are immunophenotypically distinct from mesothelioma(s). J Cutan Pathol 2000;27:451-454.
9. Yoshida $Y$, Kubota $Y$, Yamaguchi T, Iwasaki H, Nakayama J. Subcutaneous solitary fibrous tumor. J Dermatol 2004;31: 1018-1022.

10. Terada T. Solitary fibrous tumor of the shoulder showing diverse distinct histologic patterns. Int J Dermatol 2011;50: 208-211.

11. Hata H, Natsuga $K$, Aoyagi S, Homma E, Shimizu H. Solitary fibrous tumour fluctuating in size with menstrual cycle. Clin Exp Dermatol 2014;39:753-755.

12. Lee JY, Park SE, Shin SJ, Kim CW, Kim SS, Kim KH. Solitary fibrous tumor with myxoid stromal change. Am J Dermatopathol 2015;37:570-573.

13. Lee JY, Kim DH, Seo KJ, Jung SN. A solitary fibrous tumor (cellular form) of the ankle. J Foot Ankle Surg 2016;55:829831.

14. Sidney LE, Branch MJ, Dunphy SE, Dua HS, Hopkinson A. Concise review: evidence for $\mathrm{CD} 34$ as a common marker for diverse progenitors. Stem Cells 2014;32:1380-1389.

15. Sawaya JL, Khachemoune A. Superficial acral fibromyxoma. Int J Dermatol 2015;54:499-508.

16. Lee JY, Park SE, Shin SJ, Kim CW, Kim SS. Diagnostic pitfalls of differentiating cellular digital fibroma from superficial acral fibromyxoma. Ann Dermatol 2015;27:462-464.

17. Doyle LA, Vivero M, Fletcher CD, Mertens F, Hornick JL. Nuclear expression of STAT6 distinguishes solitary fibrous tumor from histologic mimics. Mod Pathol 2014;27:390395.

18. Anders JO, Aurich M, Lang T, Wagner A. Solitary fibrous tumor in the thigh: review of the literature. J Cancer Res Clin Oncol 2006;132:69-75.

19. Nielsen GP, O'Connell JX, Dickersin GR, Rosenberg AE. Solitary fibrous tumor of soft tissue: a report of 15 cases, including 5 malignant examples with light microscopic, immunohistochemical, and ultrastructural data. Mod Pathol 1997;10:1028-1037. 